\title{
ПРОГНОЗИРОВАНИЕ ФИЗИКО-ХИМИЧЕСКИХ СВОЙСТВ И ОЦЕНКА АНТИБАКТЕРИАЛЬНОЙ АКТИВНОСТИ НАНОЧАСТИЦ МЕТИОНИНАТА ЦИНКА
}

\author{
А.В. Марухленко', М.А. Морозова' \\ ${ }^{1}$ Кафедра фармацевтической и токсикологической химии, \\ Медицинский институт, Российский университет дружбы народов, \\ 117198, Россия, Москва, ул. Миклухо-Маклая, д.6.
}

DOI: 10.19163/MedChemRussia2021-2021-108

E-mail: alla.marukhlenko@yandex.ru

Известно, что использование цинка в составе хелатных комплексов позволяет снизить токсичность исходных компонентов и повысить терапевтическую эффективность хелаторов [1]. Противомикробный эффект хелатных комплексов цинка с биогенными аминокислотами $\left(\mathrm{Zn}(\mathrm{AMK})_{2}\right)$ был ранее доказан на примере глицината цинка [2]. Данная работа посвящена прогнозированию свойств Zn(AMK) 2 с помощью метода QSAR и оценке их антибактериальных Свойств.

Для аминокислот (Gly, Ala, Met, Val, Phe, Leu, Ile, Thr, Lys, Trp) и их хелатных соединений с цинком были рассчитаны топологические дескрипторы Балабана (J). Биологическая активность Gly, Ala, Met, Val, Phe и их синтезированных комплексов были изучены методом Spirotox. Антибактериальные свойства хелатных соединений 5 выбранных аминокислот оценивали по степени ингибирования образования полицеллюлярных форм в культуре клеток E. coli. Дисперсный состав исходных растворов комплексов аминокислот с цинком и совместно инкубированных образцов культуральной среды исследовали методом LALLS. Обработка данных - OriginPro 2017 (OriginLab, США).

Прогнозировано наличие линейной зависимости между структурой (J) и некоторыми свойствами (logP) хелатных комплексов, где центральный атом цинка скоординирован связями с О карбоксильной группы и $\mathrm{N}$ аминогруппы двух молекул аминокислот. Экспериментально выявлена корреляция между физико-химическими характеристиками $(\log \mathrm{P})$, токсичностью $\left(\mathrm{LD}_{50}\right)$ и биологической активностью (Еа) для 5 аминокислот и их комплексов $\mathrm{Zn}(\mathrm{AMK})_{2}$. Показано, что Zn(Met) ${ }_{2}$, как более липофильное соединение, проявляет более высокую биологическую активность в сравнении с глицинатом цинка. Все комплексы проявили антибактериальную активность в культуре E. coli. Наибольшее влияние на задержку бактериального роста оказали комплексы с метионином и аланином.

\section{Литература}

[1] Z.H. Chohan, C.T. Supuran, and A. Scozzafava. Metal binding and antibacterial activity of ciprofloxacin complexes, Journal of Enzyme Inhibition and Medicinal Chemistry. 2005, 20(3): 303-7.

[2] H.S.Shimaa, S.E. Hazem, C. Ippolito, A.S. Sadeek. Synthesis, Spectroscopic, and Biological Studies of Mixed Ligand Complexes of Gemifloxacin and Glycine with Zn(II), Sn(II), and Ce(III), Molecules. 2018, 15;23(5):1182.

$$
-108-
$$

